\title{
UDC 621.865
}

\section{INVESTIGATION OF OBJECT MANIPULATION POSITIONING ACCURACY BY BERNOULLI GRIPPING DEVICES IN ROBOTIC CELLS}

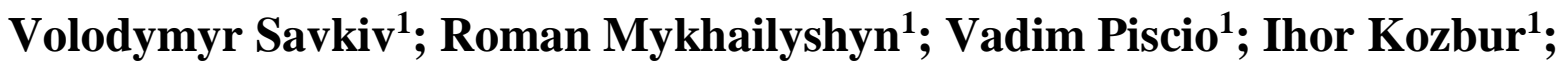 \\ Frantisek Duchon ${ }^{2}$; Lubos Chovanec ${ }^{2}$
}

\author{
${ }^{I}$ Ternopil Ivan Puluj National Technical University, Ternopil, Ukraine \\ ${ }^{2}$ Slovak University of Technology in Bratislava, Bratislava, Slovak Republic
}

\begin{abstract}
Summary. Ensuring the necessary accuracy of positioning the objects of manipulation of Bernoulli's grippers in robotic cells is an urgent task and can be achieved by choosing rational parameters of the gripping process. The article conducts experimental studies of the process of handling by Bernoulli grippers of objects of manipulation at different operating parameters and their weight. For this purpose, an experimental setup was developed, which consists of an industrial robot IRB 4600, an IRC5 controller, a Raspberry Pi microcontroller and two clock-type micrometers. The method of determining the total positioning error of the "robot-gripperobject" system is presented, which takes into account the positioning errors of the industrial robot, the errors of the gripping device and the errors of basing the object of manipulation relative to the axis of symmetry of the gripping device. The ABB IRB 1600 industrial robot was programmed in the ABB RobotStudio environment to cyclically simulate the handling operation and to determine the deviation of the position of the manipulation object after its gripping from different distances. The first cycle of automatic mode was used to calibrate the micrometer indicators, while gripping the object was carried out from a distance of $0.02 \mathrm{~mm}$. For better reliability of research results, 20 measurement cycles were performed for each of the variable parameters. As a result, it was found that the maximum base error of objects does not exceed $0.4 \mathrm{~mm}$. When capturing objects from a distance of $0.5 \ldots 1 \mathrm{~mm}$, the mean value of the base error will be $0.08 \ldots 0.15 \mathrm{~mm}$, with a standard deviation of $0.025 \ldots 0.035 \mathrm{~mm}$. The paper studies the effect of the displacement $\Delta$ of the center of mass of the gripped object relative to the axis of the Bernoulli gripper on the accuracy of the base of the objects. It is established that when the center of mass of the gripped objects is shifted relative to the Bernoulli gripper axis up to $20 \mathrm{~mm}$, the maximum base error of the objects increases 2.2 times.
\end{abstract} positioning.

Key words: industrial robot, transportation, manipulation, Bernoulli gripping device, accuracy,

Problem statement. According to the data of International Federation of Robotics (IFR) [1] which are published annually in World Robotics (Executive Summary WR 2020 Industrial Robots) [2], the global sales of robotic products decreased by 12 - to 373240 items to the amount of 13.8 billions of US dollars (without software and peripheral devices) in 2019. This happened after six years of growth and peak values.

Global economic crisis caused by pandemic COVID-19 will certainly have impact also on the sales volumes of industrial robots in 2021-2023. In the long term this crisis will stimulate digitalization creating the possibilities for further development of robotic engineering all over the world and reconstruction of the industrial robots implementation rate.

Under increasing rate of the industrial robots implementation conditions the tasks of providing the required accuracy of technological and handling operations performance have become very important. The way of objects manipulation gripping and fixing has greatly influenced the accuracy of their location and due to this the 
further actions of an robotic system are determined. In particular, the gripped object manipulation location accuracy has influenced considerably on the finished products quality, its cost and the number of spoiled products. Thus, the matter of study of objects manipulation location accuracy by gripping devices of industrial robots is an urgent problem.

Analysis of the well-known results of the research. The study of positional location accuracy, gripping force (lifting) and movements repetition in production had been initiated long before the appearance of completely robotic cells. In particular, the authors in the paper [3] have studied the accuracy and the force of gripping by an average worker in production. It was found that unlike the earlier published results all values of the accuracy and the force of gripping differred noticeably and were underestimated from those which had been determined objectively. The value of lifting capacity had a straight characteristic whereas the force of pressure and gripping possessed nonlinear value.

The modern stage of development and implementation of robotic equipment has been characterized by the gripping devices of various types use [4-7], caused by some specific features of objects manipulation and technological process. In particular, we should pay attention, that most manufacturers of gripping devices (AFAG [8], Festo [9], IPR [10], PHD [11], Zimmer Group [12], Schunk [13], SMC [14] and others) do not specify the positioning accuracy (center adjustment) of the objects in technical charactersitics but only the gripping reproduction accuracy. According to their working load capacity and range of sizes, the gripping devices [8-14] provide the positioning accuracy within the range of $0.01-0.1 \mathrm{~mm}$. Though these values of accuracy refer to the clamping grippers and do not refer to all attraction grippers. For the attraction gripping devices (vacuum [1517], swirl [18-21], magnetic [22-25], Bernoulli [26-31], cryo [32-33], electrostatic [34], frictional [35] and combined [36-41]) the gripping accuracy is not specified in the characteristics. This is because, during the gripping of the object of manipulation (OM), the gripper is at a distance or touches the stops to the object. In this way, the gripping accuracy can be determined not only by the parameters of the gripping device but by the positioning accuracy of the gripping device relative to the $\mathrm{OM}$ by the industrial robot as well.

A number of directions have been taken into consideration dealing with the required positional location accuracy assurance of the gripped OM: the object center adjustment by means of a gripper [42-43], using the accurate positioning sensors [44] and objects positioning adjustment by means of artificial vision [45-49].

The paper [42] shows a study about the theoretical centering precision for gripping devices. The deviation of the absolute axial centering is taken into account as a centering precision parameter and a general computing algorithm is developed for it. For previously developed gripping devices, using parallelogram and four-bar linkages with coupler driven jaws is computed the variation of the axial centering deviation.

In the article [43] it is shown that under increase in industrial robots (IR) demand conditions the use of cheaper industrial robots with larger positioning error under other equal conditions is quite promising. The classification of adaptive gripping devices under discussion has allowed us to determine the directions of overcoming the effects of the phenomenon «force conflict» at IR technological maintenance of working positions of machine-assembling flexible production cells and to propose some calculating schemes for adaptation units design of industrial robots gripping devices.

The paper [45] presents RF-Compass, an RFID-based system for robot navigation and object manipulation. Given an RFID-tagged object, RF-Compass accurately navigates a robot equipped with RFIDs toward the object. RF-Compass's key innovation is an iterative 
algorithm for-mulated as a convex optimization problem. The algorithm uses the RFID signals to partition the space and keeps refining the partitions based on the robot's consecutive moves.

To address these challenges, in paper [46] the ClearGrasp - a deep learning approach for estimating accurate 3D geometry of transparent objects from a single RGB-D image for robotic manipulation has been presented. Given a single RGB-D image of transparent objects, ClearGrasp uses deep convolutional networks to infer surface normals, masks of transparent surfaces, and occlusion boundaries. It then uses these outputs to refine the initial depth estimates for all transparent surfaces in the scene. The experiments have demonstrated that ClearGrasp is substantially better than monocular depth estimation baselines and is capable of generalizing to real-world images and novel objects.

Though the above-mentioned decisions have not solved the problem of OM positioning accuracy assurance gripped over a distance [50-55] by Bernoulli gripping devices, swirl or magnetic. In these cases the problem of positioning accuracy assurance was caused by the fact that prior to the moment of fixing the object of manipulation is moving uncontrolled towards the gripping device under the action of attraction force caused by this or that effect. The novelty of the study under discussion dealing with the matter of objects manipulation positioning accuracy for the group of attraction gripping devices is undoubtful, Bernoulli gripping devices in particular.

Paper purpose. To study objects manipulation positioning accuracy by Bernoulli gripping devices at the changing parameters of the gripping distance, mass center and gripped objects mass decentration.

Problem statement. The task of the paper under discussion is to study by experiments objects manipulation positioning accuracy by Bernoulli gripping devices on the basis of two grippers with a ring conic nozzle (Fig. 1). The grippers under study are positioning the object and prevent its displacement in the end face plane due to the friction forces to the protruding three friction elements (Fig. 1, a) or to the protruding conic insert (Fig. 1, b).

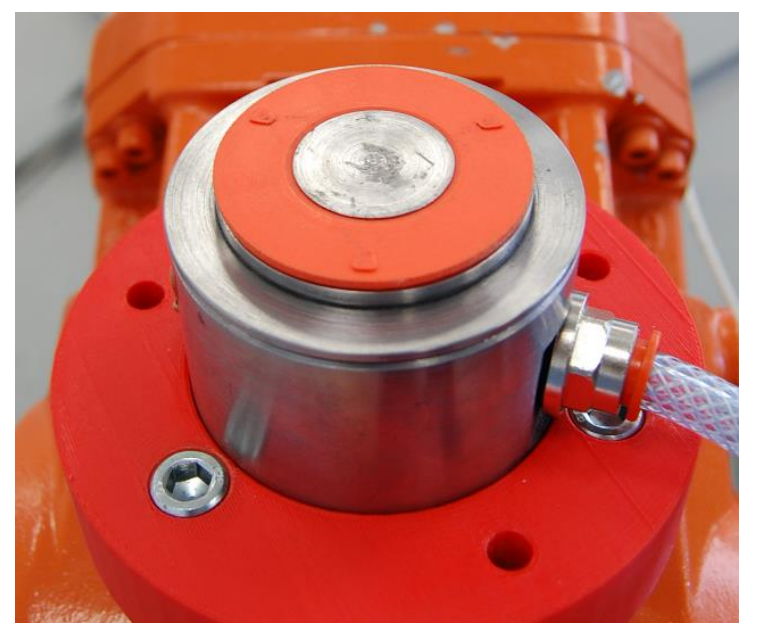

a

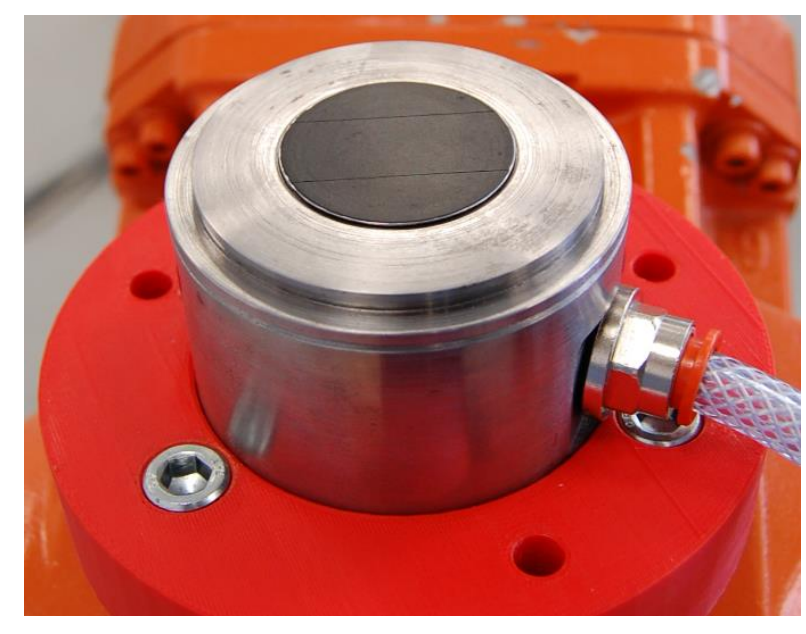

b

Figure 1. Bernoulli gripping devices:

$\mathrm{a}$ - with three points of contact, $\mathrm{b}$ - with the plane of contact

General view of the testing unit for the study of positional locating accuracy objects manipulation by Bernoulli gripping devices is shown on Fig. 2. 


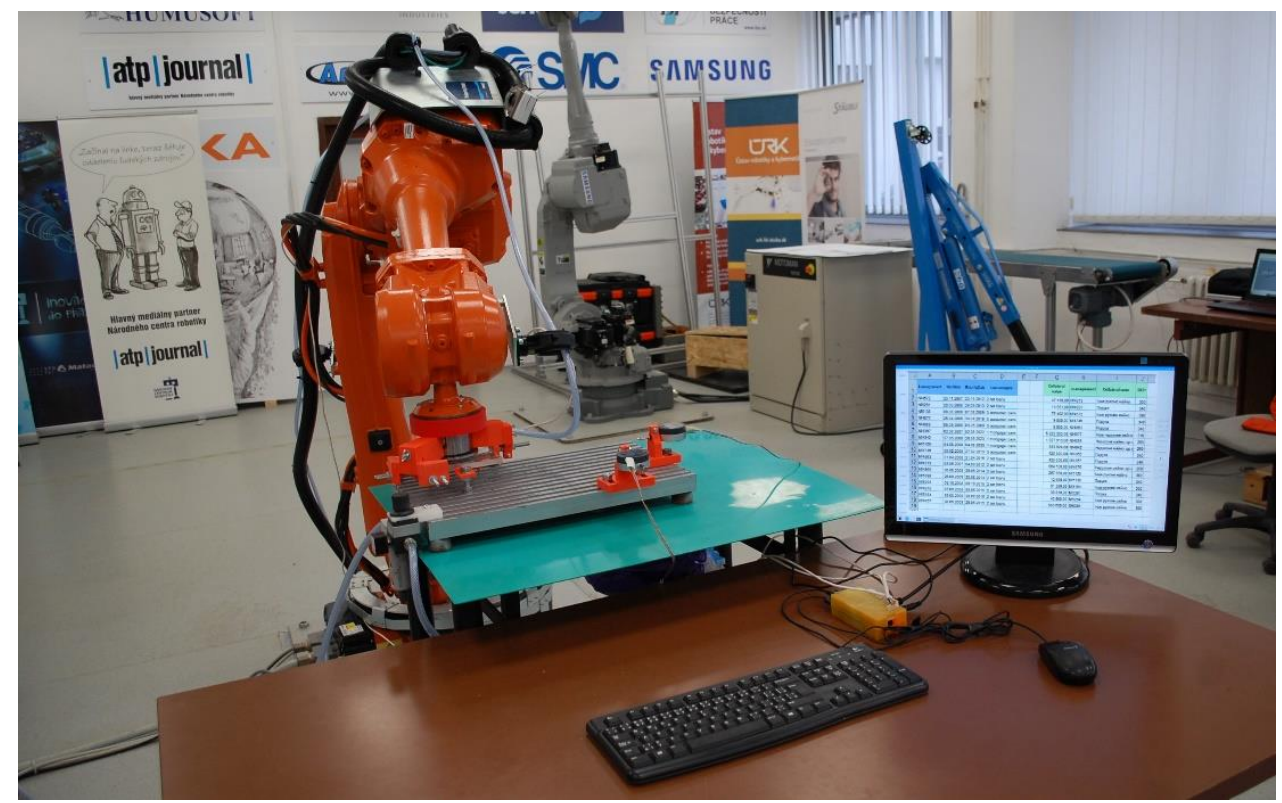

Figure 2. General view of the testing unit

Bernoulli gripping device is fastened to the flange of the industrial robot ABB IRB 1600. It is gripping an experimenatal model of the object manipulation in the form of a squre plate of $150 \times 150 \mathrm{~mm}$ size. The object is locating in the angular position of the coordinate table on special supporting clamps with side chamfers for better positioning of the object to prevent its play and its touching the clamps during the gripping (Fig. 3).

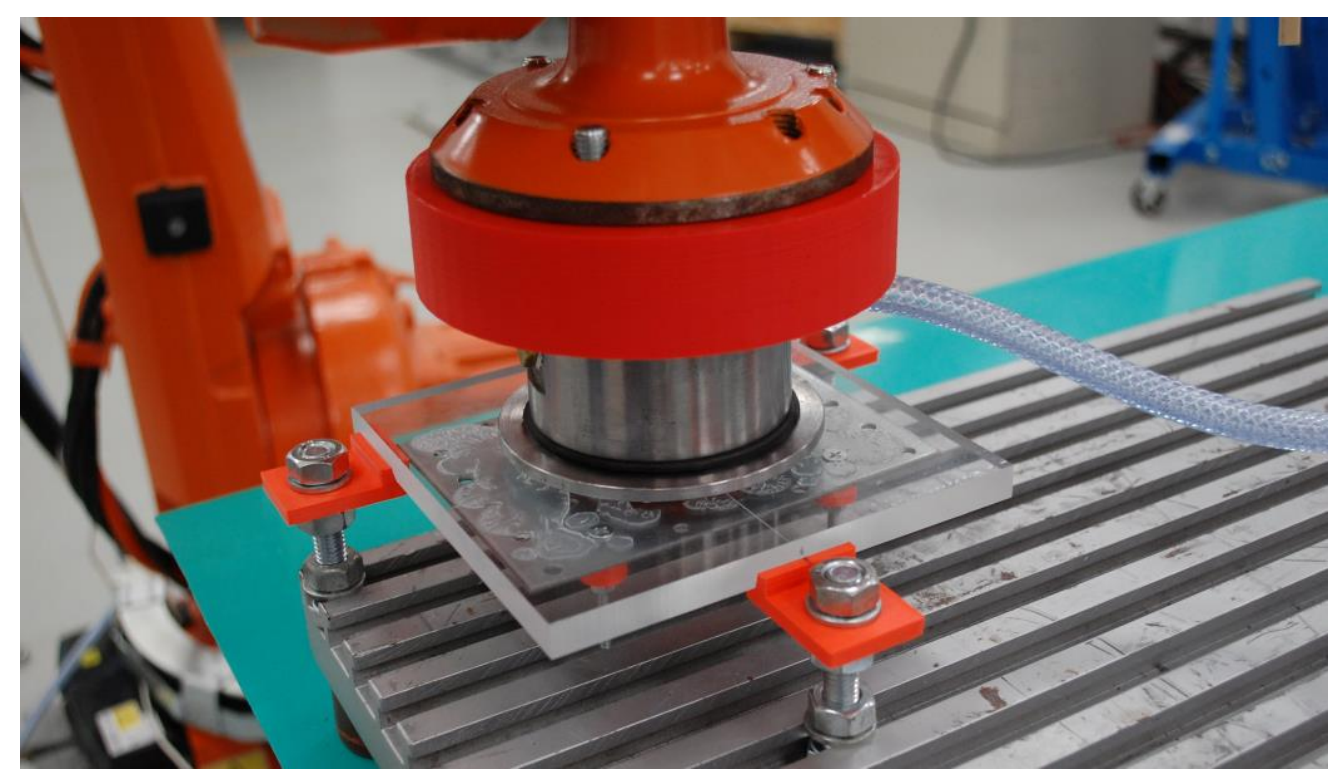

Figure 3. Initial positioning of the object manipulation on the clamps

The object manipulation mass can be varied within the range of $0.333 \ldots 1 \mathrm{~kg}$ due to the some additional metal plates fastening to it. Any deviations from the object manipulation positioning relative to the Bernoulli gripper axis have been determined by two digital micrometer indicators located at angle $90^{\circ}$ against each other and installed on the coordinate table (Fig. 4). 


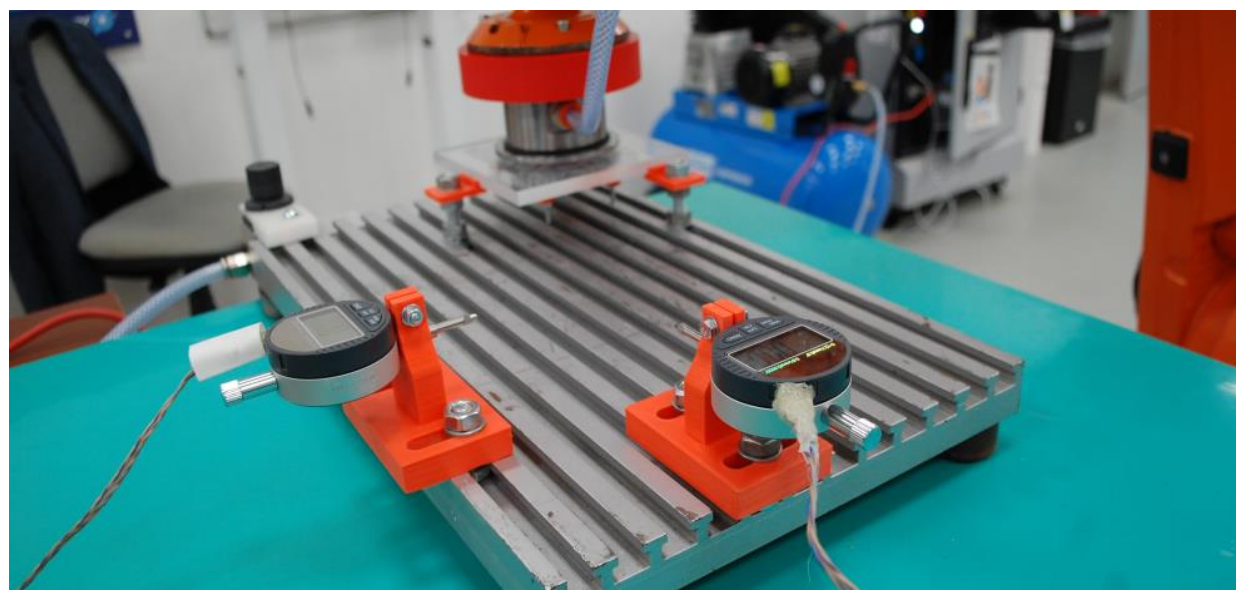

Figure 4. Installation of micrometer indicators on the coordinate table

The accuracy of micrometer indicators is $\pm 0.005 \mathrm{~mm}$. The micrometer indicators are connected to the controller Raspberry Pi to take the readings of deviations in the online mode. The object manipulation position deviations relative to the line of symmetry of the Bernoulli gripping device are measured by two coordinates $x$ and $y$. Electrical schematic diagram of the components connection of the testing unit is given on Fig. 5.

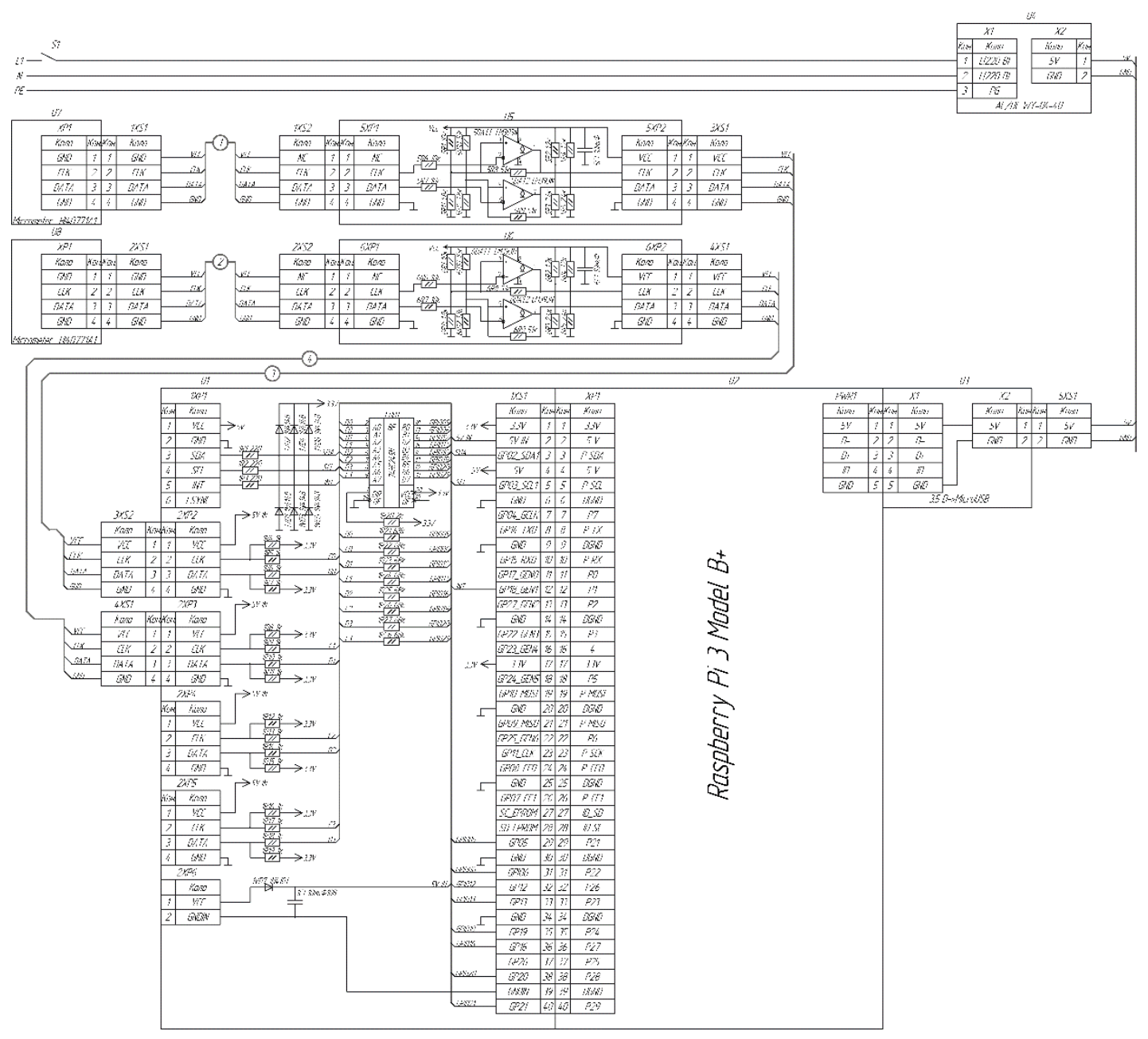

Figure 5. Electrical schematic diagram of the components connection of the testing unit 
The basis of automated experimental unit is the single-board computer Raspberry Pi 3 Model B+ (U2) built on the basis of a quad-core processor Cortex-A53 (ARM v8) operating with bit timing frequency $1,4 \mathrm{GHz}$ and has $1 \mathrm{~GB}$ random-access memory. The operating system and the user programs are stored on SD storage card included into the single-board computer.

The system power supply has been provided by power-supply unit WY-04-40 (U4), of output voltage $5 \mathrm{~V}$ and output current $4 \mathrm{~A}$. Power supply allowance is required for further development of the system. The system power supply has been provided through the adapter D5.5x2.1 - micro USB.

The position is measured by digital micrometers U7, U8 HI40771A1 having their own specific two-wire interface of logical unit voltage equal to $1.2-1.5 \mathrm{~V}$. This signal is boosted and formed due to the cards of the former amplifier (U5, U6) based on the comparator LM393N. Microelectronic circuits in adapters are switched on according to the Schmitt triggers circuit and they form signals with levels of logical 0 and 1,0 and $3.3 \mathrm{~V}$ respectively.

The formed signals from the correspondent transducers are sent to the interface adapter board U1 which relocates the signals from transudes, forms them, and sends them to 40 pin connector Raspberry Pi. Moreover, the adapter board protects the system against the misconnection of the elements. The basis of the adapter board is the microelectronic circuit $74 \mathrm{HC} 245 \mathrm{~N}$ used for amplifying and forming of the signals received from the positioning transducers. The microelectronic circuit arrangement was conducted in the mode of unidirectional buffer transmitting the signals from transducers to the correspondent contacts Raspberry Pi.

Industrial robot ABB IRB 1600 programming was taking place in the ABB RobotStudio environment [56] aimed at cyclic simulation of handling operation and determining the deviation in the object manipulation positioning after its gripping from different distance. The view of ABB RobotStudio window and the motion trajectory of the object manipulation are given on Fig. 5. The first cycle of automatic mode of operation was used for the micrometric indicators calibration, in this case the object was gripped from the distance equal to $0.02 \mathrm{~mm}$. For better validity of the results $n=20$ measuring cycles were carried out for each of varied parameters.

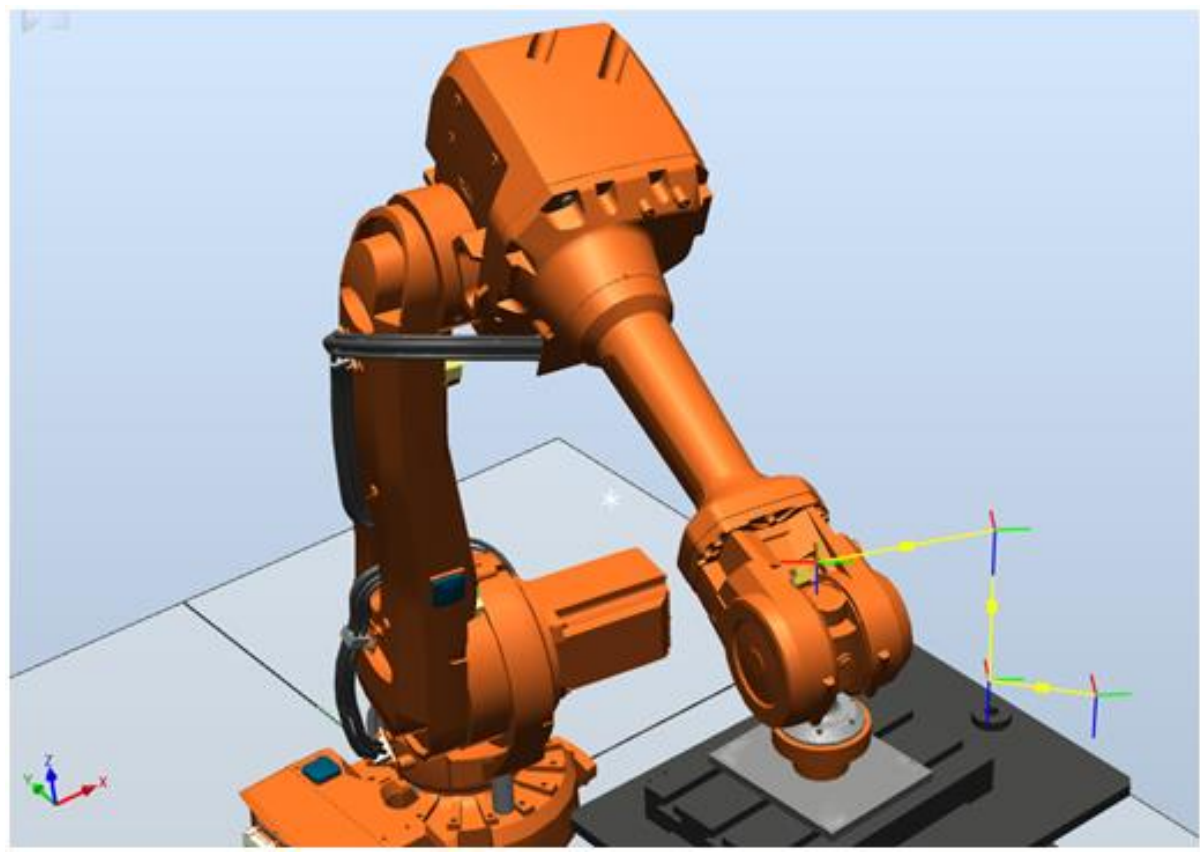

Figure 6. Visualization of the program of an industrial robot movement in the RobotStudio environment 
Accuracy and reliability of technological and handling operations performance, apart from gripping device positioning error, depend also on the industrial robot positioning error and on the clamping device positioning error (the surface of the part where the object manipulation is installed). All these three constituents represent the system «robot-gripper-object». In case of the gripper, object manipulation and clamping device axes location in the same plane, errors $\delta_{1}$, $\delta_{2}$ and $\delta_{3}$ are added and comprise the maximum error. It is clear, that the above-mentioned distribution of errors is not always the same and has a random character.

Under standard law of errors distribution conditions the distribution density is

$$
P_{p}(x)=\frac{1}{\sigma_{p} \sqrt{2 \pi}} e^{\frac{-\left(x-x_{k}\right)^{2}}{2 \sigma_{p}^{2}}},
$$

where $P_{p}(x)$ - probability for a random value to be in point $x ; \sigma_{p}$-standard deviation of the errors distribution of robot positioning, i.e. the point where the object manipulation must be.

The distribution density of the object manipulation positioning deviations relative to the gripping device axis of symmetry

$$
P_{0}(x)=\frac{1}{\sigma_{0} \sqrt{2 \pi}} e^{\frac{-\left(x-x_{k}\right)^{2}}{2 \sigma_{0}^{2}}},
$$

where $\sigma_{0}$ - standard deviation of the object positioning errors in the gripper.

The total error caused by the action of three factors

$$
\sigma_{c}=\sqrt{\sigma_{p}^{2}+\sigma_{0}^{2}+\sigma_{3}^{2}},
$$

where $\sigma_{3}-$ standard deviation of the gripping device assembling errors.

It is clear, that

$$
P(x)=\frac{1}{\sigma_{c} \sqrt{2 \pi}} e^{\frac{-\left(x-x_{k}\right)^{2}}{2 \sigma_{c}^{2}}} .
$$

Thus, providing

$$
\sum \delta=\delta_{1}+\delta_{2}+\delta_{3} \leq 3 \sigma_{c}
$$

the industrial robot is performing its task and the object will be inserted into the gripping device.

But in case

$$
\sum \delta>3 \sigma_{c}
$$

the operation specified in the program can not be carried out. In this case, the higher accuracy the object positioning in the gripping device should be achieved, or a robot with higher accuracy of repeated positioning should be applied.

The object manipulation position deviation about the Bernoulli gripping device axis of symmetry has been found in the form: 


$$
\delta_{g i}=\sqrt{\delta_{x i}^{2}+\delta_{y i}^{2}}
$$

where $\delta_{x i}, \delta_{y i}$ - experimental values of the object manipulation position deviation about axis $x$ and $y$ respectively for the $i$ experiment.

Arithmetical average $\overline{\delta_{g}}$ and standard deviation $s_{g}$ have been found by formulae:

$$
\overline{\delta_{g}}=\frac{1}{n} \sum_{i=1}^{n} \delta_{g i}, \quad s_{g}=\sqrt{\frac{1}{n-1} \sum_{i=1}^{n}\left(\delta_{g i}-\overline{\delta_{g}}\right)^{2}} .
$$

Results and discussion. The study of the impact of the gripped object mass center $\Delta$ displacement relative to the Bernoulli gripper axis on the objects positioning accuracy has been carried out in the paper under discussion. In particular, the results of the investigation of the gripping device shown on the Fig. 1, a are given in Table 1 when the air pressure in its chamber was equal to $300 \mathrm{kPa}$ and the object manipulation weight was $0.5 \mathrm{~kg}$. The distance to the object manipulation $h$ varied within $0.5 \ldots 2 \mathrm{~mm}$.

Table 1

\begin{tabular}{|c|c|c|c|c|c|c|c|c|}
\hline$h, \mathrm{~mm}$ & 0.5 & & 1.0 & & 1.5 & & 2.0 & \\
\hline$\overline{\delta_{g}} / s_{g}, \mu \mathrm{m}$ & $\overline{\overline{\delta_{g}}}$ & $S_{g}$ & $\overline{\delta_{g}}$ & $S g$ & $\overline{\delta_{g}}$ & $S_{g}$ & $\overline{\delta_{g}}$ & $S_{g}$ \\
\hline$\Delta=0$ & 13.7 & 4.7 & 37.4 & 10.4 & 83.6 & 21 & 164.1 & 40.1 \\
\hline$\Delta=10 \mathrm{~mm}$ & 17.4 & 5.1 & 66.4 & 18.9 & 91.9 & 33 & 175.2 & 39.8 \\
\hline$\Delta=20 \mathrm{~mm}$ & 24.6 & 5.2 & 88.1 & 23.6 & 118.1 & 33.3 & 182.5 & 40 \\
\hline
\end{tabular}

The results of the positioning accuracy of the OM for the gripper with three contacts

The results of the investigation of the distance $h$ impact from which the object manipulation gripping was taking place on the object displacement relative to the Bernoulli gripper axis are given on Fig. 6, 7 and 8 for the objects of weight $0.5,0.667$ and $0.834 \mathrm{~kg}$ respectively.

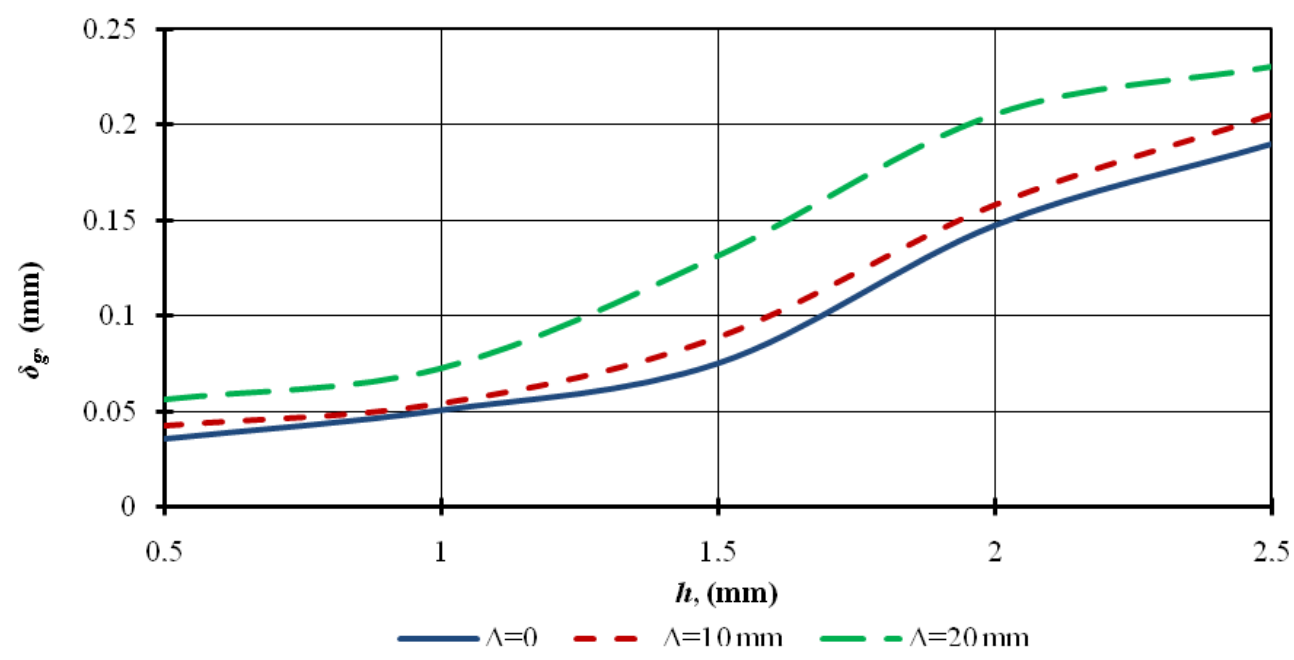

Figure 7. Graphs of dependence of positioning error on the distance to the gripped object manipulation $(m=0.5 \mathrm{~kg})$ 


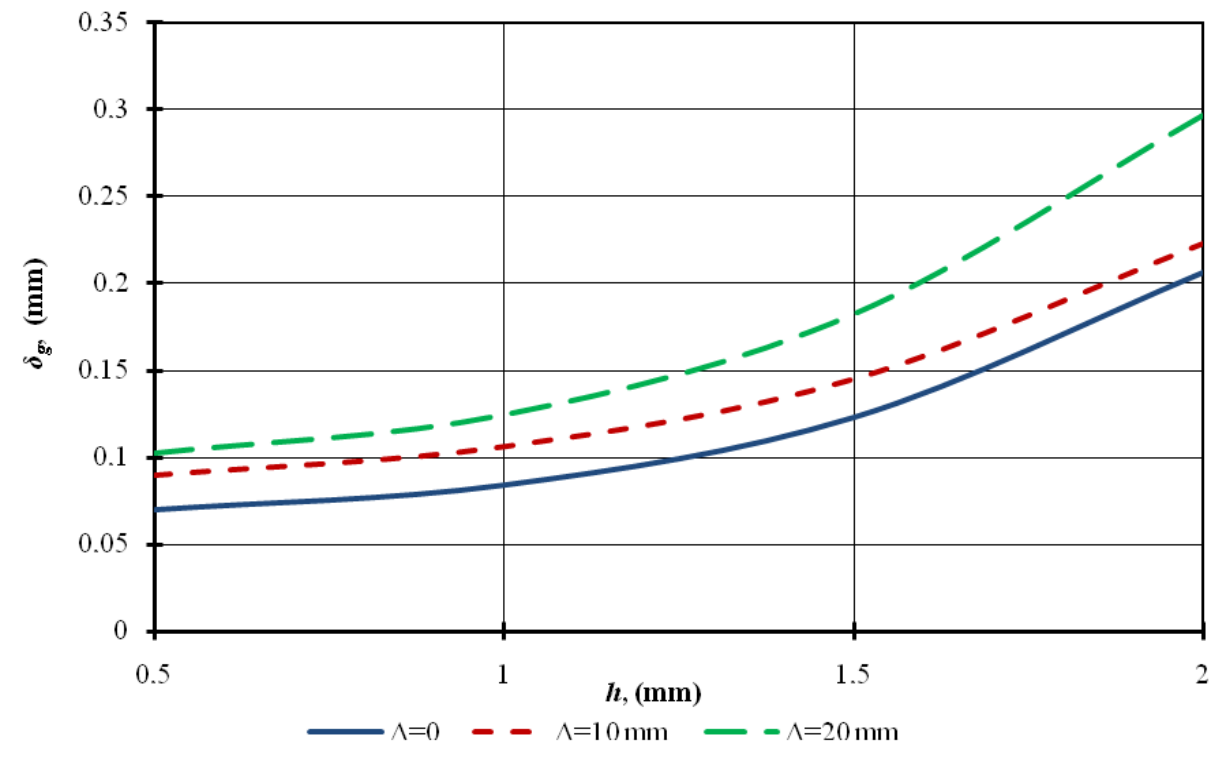

Figure 8. Graphs of dependence of positioning error on the distance to the gripped object manipulation $(m=0.667 \mathrm{~kg})$

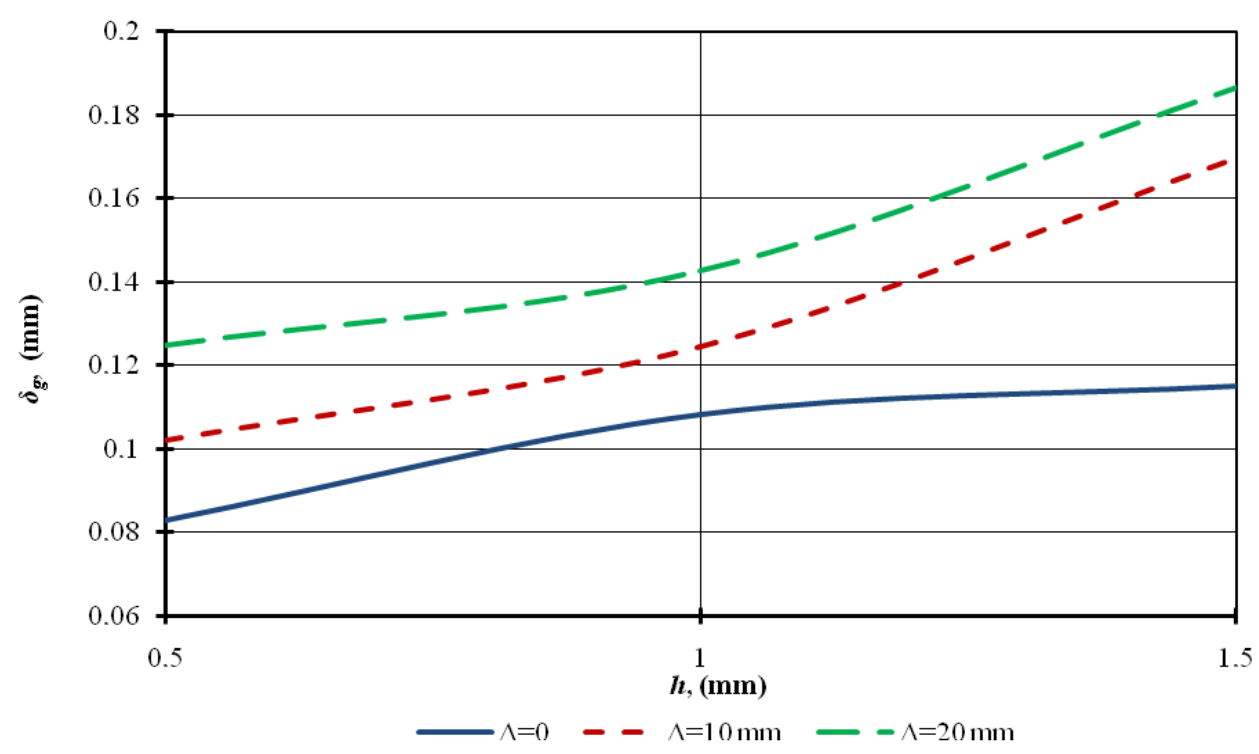

Figure 9. Graphs of dependence of positioning error on the distance to the gripped object manipulation $(m=0.834 \mathrm{~kg})$

The analysis of the above-mentioned graphs has proved the essential impact of both the distance from which these objects are being gripped and the value of the object mass center displacement relative to the Bernoulli gripper axis on the object manipulation positioning accuracy. The nature of the impact of the distance to the gripped object on the accuracy of its positioning is close to parabolical one. In case of the gripped objects mass center displacement relative to the Bernoulli gripper axis up to $20 \mathrm{~mm}$ the maximum error of the object positioning has 2.2 times increased.

The results of the experimental studies of impact of the gripped object manipulation handling weight on their positioning accuracy on the end face of the Bernoulli gripping device are given on Fig. 9, 10 and 11. 


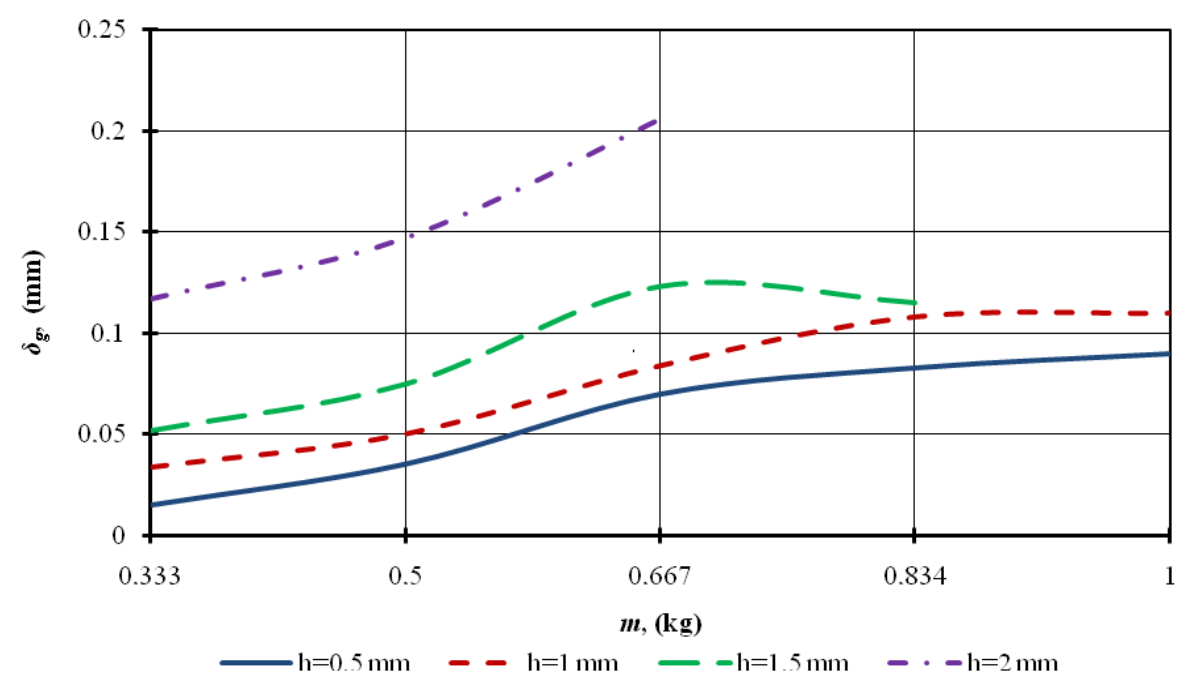

Figure 10. Graphs of dependence of objects manipulation positioning error on their weight $(\Delta=0)$

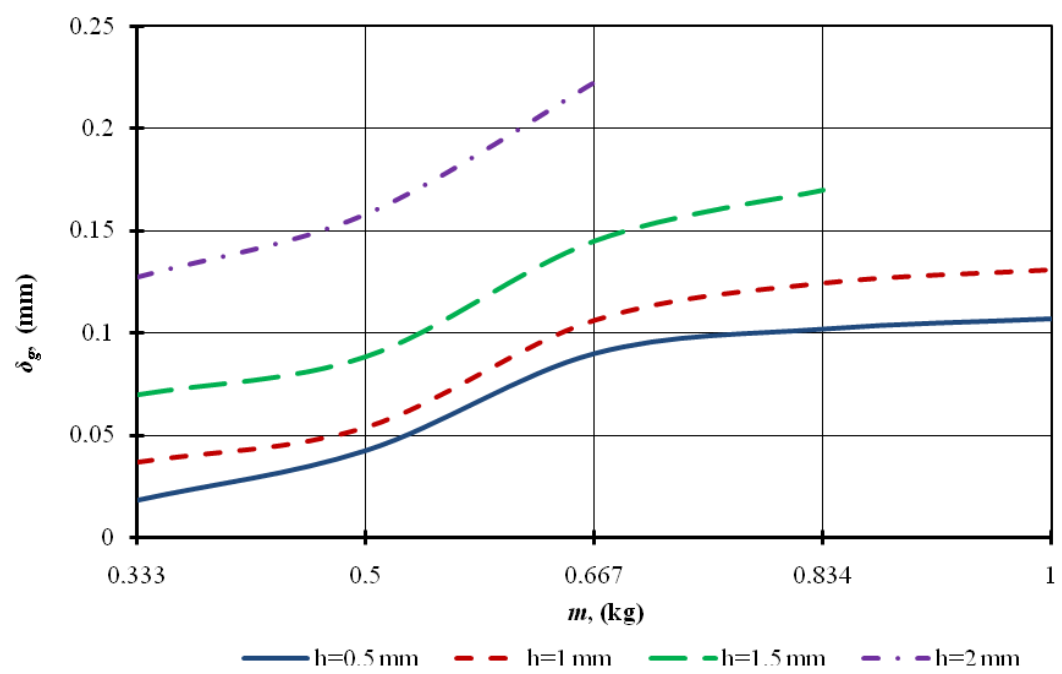

Figure 11. Graphs of dependence of objects manipulation positioning error on their weight $(\Delta=10 \mathrm{~mm})$

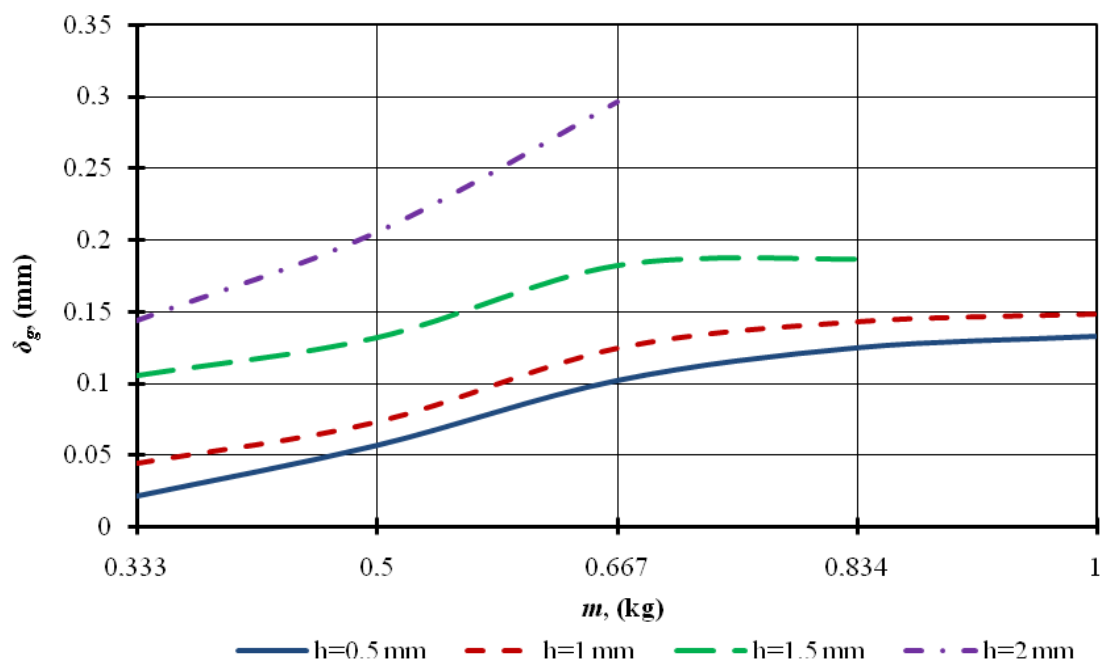

Figure 12. Graphs of dependence of objects manipulation positioning error on their weight $(\Delta=20 \mathrm{~mm})$ 
As we can see from the above-mentioned graphs, the 2 times increased weight of the error will be $0.08 \ldots 0.15 \mathrm{~mm}$ at standard deviation $0.025 \ldots 0.035 \mathrm{~mm}$. gripped objects manipulation has resulted in the objects positioning error increase in approximately $2 \ldots 4$ times.

During experimental study it was also found that the power supply pressure rise of Bernoulli grippers has caused the objects of manipulation positioning error reduction. For example, at pressure rise from 300 to $500 \mathrm{kPa}$ the positioning error for the objects of different weight was $0.42 \ldots 0.51 \%$ lower.

In general, for the range of experimental parameters change, presented in the article under discussion, the objects positioning error did not exceed $0.4 \mathrm{~mm}$. Moreover, a higher value of the error was observed at the object gripping from the distance more than $2 \mathrm{~mm}$.

In practice, the objects manipulation are being gripped by Bernoulli grippers from the distance $0.5 \ldots 1 \mathrm{~mm}$ as at larger distances the loading capacity of Bernoulli gripper has reduced abruptly. In case of object gripping from such distance the average value of positioning

Conclusions. The required accuracy assurance of the objects manipulation positioning by Bernoulli grippers has been an urgent problem and can be achieved due to the choice of the most suitable parameters of the gripping process. The experimental studies of the Bernoulli grippers at different operation parameters and various objects manipulation weight have proved, that the maximum error of the objects under discussion positioning does not exceed $0.4 \mathrm{~mm}$. The technique under discussion on finding the summed error of the system «robotgripper-object» positioning has allowed us to determine the reliability of handling or assembling operation. In case of grippping the objects from the distance $0.5 \ldots 1 \mathrm{~mm}$ the average value of the positioning error was $0.08 \ldots 0.15 \mathrm{~mm}$, at standard deviation $0.025 \ldots 0.035 \mathrm{~mm}$. In case of mass decentration of the gripped objects relative to the Bernoulli gripper axis up to $20 \mathrm{~mm}$ the maximum objects positioning error is 2.2 times increased.

\section{References}

1. International Federation of Robotics. URL: https://ifr.org/.

2. World Robotics 2020 - Industrial Robots and Service Robots. URL: https://ifr.org/worldrobotics.

3. Kumar S., Narayan Y., \& Chouinard K. Effort reproduction accuracy in pinching, gripping, and lifting among industrial males. International Journal of Industrial Ergonomics. Vol. 20. No. 2. 1997. P. 109-119. DOI: https://doi.org/10.1016/S0169-8141(96)00045-5

4. Fantoni G., Santochi M., Dini G., Tracht K., Scholz-Reiter B., Fleischer J., and Hansen H.N., Grasping devices and methods in automated production processes. CIRP Annals-Manufacturing Technology. Vol. 63. No. 2. 2014. P. 679-701. DOI: https://doi.org/10.1016/j.cirp.2014.05.006

5. Monkman G. J., Hesse S., Steinmann R., Schunk H. Robot grippers, Weinheim: John Wiley \& Sons, KGaA, 2007, 452 p. DOI: https://doi.org/10.1002/9783527610280

6. Carbone G. Grasping in robotics, Springer-Verlag London, 2012, 468 p. DOI: https://doi.org/10.1007/978-1-4471-4664-3

7. Wolf A., Schunk H. A., Grippers in motion: the fascination of automated handling tasks, Carl Hanser Verlag GmbH Co KG, 2018. DOI: https://doi.org/10.3139/9781569907153

8. Afag, Gripper Moduls. URL: https://www.afag.com/en/handling/handling-systems.html.

9. Festo, Catalogs. URL: https://www.festo.com/cat/ru-uk_ua/products_010800.

10.IPR, Intelligente Peripherien fur Roboter GmbH, Catalogs. URL: https://en.iprworldwide.com/ category/grippers/.

11. PHD Inc., Catalogs. URL: https://www.phdinc.com/products/category/?product=grippers.

12.Zimmer Group Canada Inc., Catalogs. URL: https://www.zimmer-group.com/en/technologiescomponents/handling-technology/grippers.

13. Schunk GmbH, Gripping Moduls. URL: https://schunk.com/de_en/gripping-systems/category/grippingsystems/schunk-grippers/.

14. SMC, Catalogs. URL: https://www.smcusa.com/products/actuators/grippers 20234.

15. Li S., Stampfli J. J., Xu H. J., Malkin E., Diaz E. V., Rus D., \& Wood R. J. A vacuum-driven origami "magic-ball" soft gripper, In 2019 International Conference on Robotics and Automation (ICRA). 2019. May. P. 7401-7408. DOI: https://doi.org/10.1109/ICRA.2019.8794068

16. Makarov A. M., Mushkin O. V., \& Lapikov M. A. Use of additive technologies to increase effectiveness of design and use of a vacuum gripping devices for flexible containers, In MATEC Web of Conferences. Vol. 224. 2018. DOI: https://doi.org/10.1051/matecconf/201822401082

17. Kim J. H., \& Lee S. J. Configuration of noncontact grip system for carrying large flat sheets using vacuum air heads. Journal of Tribology. Vol. 137. No. 4. 2015. DOI: https://doi.org/10.1115/1.4030710 
18. Morimoto K., Tada Y., Takashima H., Minamino K., Tahara R., \& Konishi S. Design and characterization of high-performance contactless gripper using spiral air flows, In 2010 International Symposium on Micro-NanoMechatronics and Human Science. 2010. November. P. 423-428. DOI: https://doi.org/10.1109/MHS.2010.5669510

19. Zhao J., Wang C., \& Li X. Gap flow with circumferential velocity in annular skirt of vortex gripper, Precision Engineering. Vol. 57. 2019. P. 64-72. DOI: https://doi.org/10.1016/j.precisioneng.2019.03.007

20.Wang C., Zhao J., \& Li X. Effect of chamber diameter of vortex gripper on maximum suction force and flow field. Advances in Mechanical Engineering. Vol. 11. No. 3. 2019. DOI: https://doi.org/10.1177/1687814019837401

21. Roy D. Development of novel magnetic grippers for use in unstructured robotic workspace, Robotics and Computer-Integrated Manufacturing. Vol. 35. 2015. P. 16-41. DOI: https://doi.org/10.1016/j.rcim.2015.02.003

22. Gawel A., Kamel M., Novkovic T., Widauer J., Schindler D., Von Altishofen B. P., \& Nieto J. Aerial picking and delivery of magnetic objects with mavs, In 2017 IEEE international conference on robotics and automation (ICRA). 2017. May. P. 5746- 5752. DOI: https://doi.org/10.1109/ICRA.2017.7989675

23. Chen C., \& Chung T. A novel thermomagnetic gripper, In 2015 IEEE International Magnetics Conference (INTERMAG). 2015. May. P. 1-11. DOI: https://doi.org/10.1109/INTMAG.2015.7157658

24. Fiaz U. A., Abdelkader M., \& Shamma J. S. An intelligent gripper design for autonomous aerial transport with passive magnetic grasping and dual-impulsive release, In 2018 IEEE/ASME International Conference on Advanced Intelligent Mechatronics (AIM). 2018. July. P. 1027-1032. DOI: https://doi.org/10.1109/AIM.2018.8452383

25. Liu D., Wang M., Fang N., Cong M., \& Du Y. Design and tests of a non-contact Bernoulli gripper for rough-surfaced and fragile objects gripping, Assembly Automation. 2020. DOI: https://doi.org/10.1108/AA-10-2019-0171

26. Savkiv V., Mykhailyshyn R., Duchon F. Gasdynamic analysis of the Bernoulli grippers interaction with the surface of flat objects with displacement of the center of mass. Vacuum. No. 159. 2019. P. 524-533. DOI: https://doi.org/10.1016/j.vacuum.2018.11.005

27. Shi K., \& Li X. Experimental and theoretical study of dynamic characteristics of Bernoulli gripper. Precision Engineering. Vol. 52. 2018. P. 323-331. DOI: https://doi.org/10.1016/j.precisioneng.2018.01.006

28. Savkiv V., Mykhailyshyn R., Fendo O., Mykhailyshyn M. Orientation Modeling of Bernoulli Gripper Device with Off-Centered Masses of the Manipulating Object. Procedia Engineering. No. 187. 2017. P. 264-271. DOI: https://doi.org/10.1016/j.proeng.2017.04.374

29. Mykhailyshyn R., Savkiv V., Duchon F., Mikhalishin M. Energy efficiency analysis of the manipulation process by the industrial objects with the use of Bernoulli gripping devices. Journal of Electrical Engineering. Vol. 68. No. 6. 2017. P. 496-502. DOI: https://doi.org/10.1515/jee-2017-0087

30. Mykhailyshyn R., Savkiv V., Mikhalishin M., Duchon F. Experimental Research of the Manipulatiom Process by the Objects Using Bernoulli Gripping Devices, In Young Scientists Forum on Applied Physics and Engineering. International IEEE Conference. 2017. P. 8-11. DOI: https://doi.org/10.1109/YSF.2017.8126583

31. Seliger G., Stephan J., \& Lange S. Non-rigid part handling by new gripping device, In Proc 8th Intl Conf Manuf Eng, ICME2000, Sydney, Australi. 2000. P. 423-427.

32. Buljo J. O., \& Gjerstad T. B. Robotics and automation in seafood processing, In Robotics and Automation in the Food Industry. 2013. P. 354-384. DOI: https://doi.org/10.1533/9780857095763.2.354

33. Brecher C., Kukla C., Schares R., Emonts M., Haus M. Form-Adaptive Gripping System for Light-Weight Productions, In 20th International Conference on Composite Materials. 2015. P. 19-24.

34. Hawkes E. W., Christensen D. L., Han A. K., Jiang H., \& Cutkosky M. R. Grasping without squeezing: Shear adhesion gripper with fibrillar thin film, In 2015 IEEE International Conference on Robotics and Automation (ICRA). 2015. May. P. 2305 -2312. DOI: https://doi.org/10.1109/ICRA.2015.7139505

35. Förster F., Ballier F., Coutandin S., Defranceski A., Fleischer J. Manufacturing of textile preforms with an intelligent draping and gripping system. Procedia CIRP. No. 66. 2017. P. $39-44$. DOI: https://doi.org/10.1016/j.procir.2017.03.370

36. Savkiv V., Mykhailyshyn R., Duchon F., Fendo O. Justification of Design and Parameters of Bernoulli-Vacuum Gripping Device. International Journal of Advanced Robotic Systems. 2017. DOI: https://doi.org/10.1177/1729881417741740

37. Mykhailyshyn R., Savkiv V., Diahovchenko I., Duchon F., Trembach R. Research of Energy Efficiency of Manipulation of Dimensional Objects With the Use of Pneumatic Gripping Devices. IEEE 2nd Ukraine Conference on Electrical and Computer Engineering UKRCON-2019. 2019. P. 527-532. DOI: https://doi.org/10.1109/UKRCON.2019.8879957

38. Jørgensen T. B., Krüger N., Pedersen M. M., Hansen N. W., Hansen B. R. Designing a Flexible Grasp Tool and Associated Grasping Strategies for Handling Multiple Meat Products in an Industrial Setting. International Journal of Mechanical Engineering and Robotics Research. Vol. 8. No. 2. 2019. P. $220-227$. DOI: https://doi.org/10.18178/ijmerr.8.2.220-227

39. Fleischer J., Förster F., \& Gebhardt J. Sustainable manufacturing through energy efficient handling processes. Procedia CIRP. Vol. 40. 2016. P. 574-579. DOI: https://doi.org/10.1016/j.procir.2016.01.136 
40. Fleischer J., Ochs A., \& Förster F. Gripping technology for carbon fibre material, In CIRP International conference on competitive manufacturing, Band: Green manufacturing for a blue planet. 2013. P. 65-71.

41. Lien T. K., \& Davis P. G. G. A novel gripper for limp materials based on lateral Coanda ejectors. CIRP annals. Vol. 57. No. 1. 2008. P. 33-36. DOI: https://doi.org/10.1016/j.cirp.2008.03.119

42. Lovasz E. C., Mesaroş-Anghel V., Gruescu C. M., Moldovan C. E., \& Ceccarelli M. General Algorithm for Computing the Theoretical Centering Precision of the Gripping Devices, In Advances in Mechanism Design II. 2017. P. 15-21. DOI: https://doi.org/10.1007/978-3-319-44087-3_2

43. Kyrylovych V. A., Cherepans'ka I. Yu., \& Sazonov A. Yu. 2010, Adaptyvnist' skhvativ promyslovykh robotiv yak napryam pidvyshchennya efektyvnosti robotyzovanykh mekhanoskladal'nykh tekhnolohiy. Bulletin of ZhSTU. Series «Technical Sciences». Vol. 1. No. 52. P. 17-24. [In Ukrainian].

44. Rong W., Liang S., Wang L., Zhang S., \& Zhang W. Model and control of a compact long-travel accuratemanipulation platform. IEEE/ASME Transactions on Mechatronics. Vol. 22. No. 1. 2016. P. $402-411$. DOI: https://doi.org/10.1109/TMECH.2016.2597168

45. Wang J., Adib F., Knepper R., Katabi D., \& Rus D. RF-compass: Robot object manipulation using RFIDs, In Proceedings of the 19th annual international conference on Mobile computing \& networking. 2013. September. P. 3-14. DOI: https://doi.org/10.1145/2500423.2500451

46. Sajjan S., Moore M., Pan M., Nagaraja G., Lee J., Zeng A., \& Song S. Clear Grasp: 3D Shape Estimation of Transparent Objects for Manipulation. In 2020 IEEE International Conference on Robotics and Automation (ICRA). 2020. May. P. 3634-3642. DOI: https://doi.org/10.1109/ICRA40945.2020.9197518

47. Aulin V. V., Pankov A. O., Zamota T. M., Lyashuk O. L., Hrynkiv A. V., Tykhyi A. A., Kuzyk A. V., Development of mechatronic module for the seeding control system. INMATEH - Agricultural Engineering. Vol. 59. No. 3. 2019. P. 1-8. DOI: https://doi.org/10.35633/INMATEH-59-20

48. Aulin V., Hrynkiv A., Lyashuk O., Vovk Y., Lysenko S., Holub D., Zamota T., Pankov A., Sokol M., Ratynskyi V., Lavrentieva O. Increasing the functioning efficiency of the working warehouse of the «Uvk Ukraine» company transport and logistics center, Communications - Scientific Letters of the University of Zilina. Vol. 22. No. 2. 2020. P. 3-14. DOI: https://doi.org/10.26552/com.C.2020.2.3-14

49. Collet A., Berenson D., Srinivasa S. S., \& Ferguson D. Object recognition and full pose registration from a single image for robotic manipulation. In 2009 IEEE International Conference on Robotics and Automation. 2009. May. P. 48-55. DOI: https://doi.org/10.1109/ROBOT.2009.5152739

50. Savkiv V., Mykhailyshyn R., Duchon F., Mikhalishin M. Modeling of Bernoulli gripping device orientation when manipulating objects along the arc, International Journal of Advanced Robotic Systems, 2018. DOI: https://doi.org/10.1177/1729881418762670

51. Mykhailyshyn R., Savkiv V., Duchon F., Koloskov V., Diahovchenko I. Investigation of the energy consumption on performance of handling operations taking into account parameters of the grasping system, 2018 IEEE 3rd International Conference on Intelligent Energy and Power Systems (IEPS). 2018. P. 295300. DOI: https://doi.org/10.1109/IEPS.2018.8559586

52. Mykhailyshyn R., Savkiv V., Duchon F., Maruschak P., Prentkovskis O. Substantiation of Bernoulli Grippers Parameters at Non-Contact Transportation of Objects with a Displaced Center of Mass, 22nd International Scientific Conference Transport Means 2018. Klaipeda. 2018. P. 1370-1375.

53. Mykhailyshyn R., Savkiv V., Duchon F., Chovanec L. Experimental Investigations of the Dynamics of Contactless Transportation by Bernoulli Grippers, 2020 IEEE 6th International Conference on Methods and Systems of Navigation and Motion Control (MSNMC). 2020. P. 97-100. DOI: https://doi.org/10.1109/MSNMC50359.2020.9255521

54. Mykhailyshyn R., Savkiv V., Boyko I., Prada E., \& Virgala, I. Substantiation of Parameters of Friction Elements of Bernoulli Grippers With a Cylindrical Nozzle. International Journal of Manufacturing, Materials, and Mechanical Engineering (IJMMME). Vol. 11. No. 2. 2021. P. 17-39. DOI: https://doi.org/10.4018/IJMMME.2021040102

55. Giesen T., Wertz R., Fischmann C., Kreck G., Govaerts J., Vaes J., \& Verl A. Advanced production challenges for automated ultra-thin wafer handling, In Proc. 27th Eur. Photovoltaic Sol. Energy Conf. Exhib., 2012, September. P. 1165-1170.

56. Official website of ABB Robotics, RobotStudio. URL: http://new.abb.com/products/robotics/robotstudio.

\section{Список використаної літератури}

1. International Federation of Robotics. URL: https://ifr.org/.

2. World Robotics 2020 - Industrial Robots and Service Robots. URL: https://ifr.org/worldrobotics.

3. Kumar S., Narayan Y., \& Chouinard K. Effort reproduction accuracy in pinching, gripping, and lifting among industrial males. International Journal of Industrial Ergonomics. 1997. № 20 (2). P. 109-119. DOI: https://doi.org/10.1016/S0169-8141(96)00045-5

4. Fantoni G., Santochi M., Dini G., Tracht K., Scholz-Reiter B., Fleischer J., and Hansen H. N. Grasping devices and methods in automated production processes. CIRP Annals-Manufacturing Technology. 2014. № 63 (2). P. 679-701. DOI: https://doi.org/10.1016/j.cirp.2014.05.006

5. Monkman G. J., Hesse S., Steinmann R., Schunk H. Robot grippers. Weinheim: John Wiley \& Sons. KGaA, 2007. 452 p. DOI: https://doi.org/10.1002/9783527610280 
6. Carbone G. Grasping in robotics, Springer-Verlag London, 2012, 468 p. DOI: https://doi.org/10.1007/978-1-4471-4664-3

7. Wolf A., Schunk H. A., Grippers in motion: the fascination of automated handling tasks. Carl Hanser Verlag GmbH Co KG. 2018. DOI: https://doi.org/10.3139/9781569907153

8. Офіційний web сайт Afag, Gripper Moduls. URL: https://www.afag.com/en/handling/handlingsystems.html.

9. Офіційний web сайт Festo, Catalogs. URL: https://www.festo.com/cat/ru-uk_ua/products_010800.

10. Офіційний web сайт IPR, Intelligente Peripherien fur Roboter GmbH, Catalogs. URL: https://en. iprworldwide.com/category/grippers/.

11. Офіційний web сайт PHD Inc., Catalogs. URL: https://www.phdinc.com/products/category/?product =grippers.

12. Офіційний web сайт Zimmer Group Canada Inc., Catalogs. URL: https://www.zimmer-group.com/ en/technologies-components/handling-technology/grippers.

13. Офіційний web сайт Schunk GmbH, Gripping Moduls. URL: https://schunk.com/de_en/grippingsystems/category/gripping-systems/schunk-grippers/.

14. Офіційний web сайт SMC, Catalogs. URL: https://www.smcusa.com/products/actuators/grippers 20234.

15. Li S., Stampfli J. J., Xu H. J., Malkin E., Diaz E. V., Rus D., \& Wood R. J. A vacuum-driven origami «magic-ball» soft gripper. In 2019 International Conference on Robotics and Automation (ICRA). 2019. May. P. 7401-7408. DOI: https://doi.org/10.1109/ICRA.2019.8794068

16. Makarov A. M., Mushkin O. V., Lapikov M. A. Use of additive technologies to increase effectiveness of design and use of a vacuum gripping devices for flexible containers. In MATEC Web of Conferences. Vol. 224. 2018. DOI: https://doi.org/10.1051/matecconf/201822401082

17. Kim J. H., Lee S. J. Configuration of noncontact grip system for carrying large flat sheets using vacuum air heads. Journal of Tribology. 2015. Vol. 137. No. 4. 2015. DOI: https://doi.org/10.1115/1.4030710

18. Morimoto K., Tada Y., Takashima H., Minamino K., Tahara R., Konishi S. Design and characterization of high-performance contactless gripper using spiral air flows. In 2010 International Symposium on Micro-NanoMechatronics and Human Science. 2010. November. P. 423-428. DOI: https://doi.org/10.1109/MHS.2010.5669510

19. Zhao J., Wang C., Li X., Gap flow with circumferential velocity in annular skirt of vortex gripper. Precision Engineering. 2019. № 57. P. 64-72. DOI: https://doi.org/10.1016/j.precisioneng.2019.03.007

20. Wang C., Zhao J., Li X. Effect of chamber diameter of vortex gripper on maximum suction force and flow field. Advances in Mechanical Engineering. 2019. № 11 (3). DOI: https://doi.org/10.1177/1687814019837401

21. Roy D. Development of novel magnetic grippers for use in unstructured robotic workspace. Robotics and Computer-Integrated Manufacturing. 2015. № 35. P. 16-41. DOI: https://doi.org/10.1016/j.rcim.2015.02.003

22. Gawel A., Kamel M., Novkovic T., Widauer J., Schindler D., Von Altishofen B. P., Nieto J. Aerial picking and delivery of magnetic objects with mavs. In 2017 IEEE international conference on robotics and automation (ICRA). 2017. May. P. 5746-5752. DOI: https://doi.org/10.1109/ICRA.2017.7989675

23. Chen C., Chung T. A novel thermomagnetic gripper. In 2015 IEEE International Magnetics Conference (INTERMAG). 2015. May. P. 1-1. DOI: https://doi.org/10.1109/INTMAG.2015.7157658

24. Fiaz U. A., Abdelkader M., Shamma J. S. An intelligent gripper design for autonomous aerial transport with passive magnetic grasping and dual-impulsive release. In 2018 IEEE/ASME International Conference on Advanced Intelligent Mechatronics (AIM). 2018, July. P. 1027-1032. DOI: https://doi.org/10.1109/AIM.2018.8452383

25. Liu D., Wang M., Fang N., Cong M., Du Y. Design and tests of a non-contact Bernoulli gripper for rough-surfaced and fragile objects gripping. Assembly Automation. 2020. DOI: https://doi.org/10.1108/AA-10-2019-0171

26. Savkiv V., Mykhailyshyn R., Duchon F. Gasdynamic analysis of the Bernoulli grippers interaction with the surface of flat objects with displacement of the center of mass. Vacuum. 2019. № 159. P. 524-533. DOI: https://doi.org/10.1016/j.vacuum.2018.11.005

27. Shi K., Li X. Experimental and theoretical study of dynamic characteristics of Bernoulli gripper. Precision Engineering. 2018. № 52. P. 323-331. DOI: https://doi.org/10.1016/j.precisioneng.2018.01.006

28. Savkiv V., Mykhailyshyn R., Fendo O., Mykhailyshyn M. Orientation Modeling of Bernoulli Gripper Device with Off-Centered Masses of the Manipulating Object. Procedia Engineering. 2017. № 187. P. 264271. DOI: https://doi.org/10.1016/j.proeng.2017.04.374

29. Mykhailyshyn R., Savkiv V., Duchon F., Mikhalishin M. Energy efficiency analysis of the manipulation process by the industrial objects with the use of Bernoulli gripping devices. Journal of Electrical Engineering. 2017. № 68 (6). P. 496-502. DOI: https://doi.org/10.1515/jee-2017-0087

30. Mykhailyshyn R., Savkiv V., Mikhalishin M., Duchon F. Experimental Research of the Manipulatiom Process by the Objects Using Bernoulli Gripping Devices / R. Mykhailyshyn. In Young Scientists Forum on Applied Physics and Engineering, International IEEE Conference. 2017. P. 8-11. DOI: https://doi.org/10.1109/YSF.2017.8126583

31. Seliger G., Stephan J., Lange S. Non-rigid part handling by new gripping device. In Proc 8th Intl Conf Manuf Eng. ICME 2000. Sydney. Australia. 2000. P. 423-427. 
32. Buljo J. O., Gjerstad T. B. Robotics and automation in seafood processing. In Robotics and Automation in the Food Industry. 2013. P. 354-384. DOI: https://doi.org/10.1533/9780857095763.2.354

33. Brecher C., Kukla C., Schares R., Emonts M., Haus M. Form-Adaptive Gripping System for Light-Weight Productions. In 20th International Conference on Composite Materials. 2015. P. 19-24.

34. Hawkes E. W., Christensen D. L., Han A. K., Jiang H., Cutkosky M. R. Grasping without squeezing: Shear adhesion gripper with fibrillar thin film. In 2015 IEEE International Conference on Robotics and Automation (ICRA). 2015. May. P. 2305-2312. DOI: https://doi.org/10.1109/ICRA.2015.7139505

35. Förster F., Ballier F., Coutandin S., Defranceski A., Fleischer J. Manufacturing of textile preforms with an intelligent draping and gripping system. Procedia CIRP. 2017. № 66. P. 39-44. DOI: https://doi.org/10.1016/j.procir.2017.03.370

36. Savkiv V., Mykhailyshyn R., Duchon F., Fendo O. Justification of Design and Parameters of BernoulliVacuum Gripping Device. International Journal of Advanced Robotic Systems. 2017. DOI: https://doi.org/10.1177/1729881417741740

37. Mykhailyshyn R., Savkiv V., Diahovchenko I., Duchon F., Trembach R. Research of Energy Efficiency of Manipulation of Dimensional Objects With the Use of Pneumatic Gripping Devices. 2019 IEEE 2nd Ukraine Conference on Electrical and Computer Engineering UKRCON-2019 - IEEE, 2019. P. 527-532. DOI: https://doi.org/10.1109/UKRCON.2019.8879957

38. Jørgensen T. B., Krüger N., Pedersen M. M., Hansen N. W., Hansen B. R. Designing a Flexible Grasp Tool and Associated Grasping Strategies for Handling Multiple Meat Products in an Industrial Setting. International Journal of Mechanical Engineering and Robotics Research. Vol. 8. No. 2. 2019. P. $220-227$. DOI: https://doi.org/10.18178/ijmerr.8.2.220-227

39. Fleischer J., Förster F., Gebhardt J. Sustainable manufacturing through energy efficient handling processes. Procedia CIRP. 2016. № 40. P. 574-579. DOI: https://doi.org/10.1016/j.procir.2016.01.136

40. Fleischer J., Ochs A., Förster F. Gripping technology for carbon fibre material. In CIRP International conference on competitive manufacturing, Band: Green manufacturing for a blue planet. 2013. P. 65-71.

41. Lien T. K., Davis P. G. G. A novel gripper for limp materials based on lateral Coanda ejectors. CIRP annals. 2008. № 57 (1). P. 33-36. DOI: https://doi.org/10.1016/j.cirp.2008.03.119

42. Lovasz E. C., Mesaroş-Anghel V., Gruescu C. M., Moldovan C. E., Ceccarelli M. General Algorithm for Computing the Theoretical Centering Precision of the Gripping Devices. In Advances in Mechanism Design II. 2017. P. 15-21. DOI: https://doi.org/10.1007/978-3-319-44087-3_2

43. Кирилович В. А., Черепанська І. Ю., Сазонов А. Ю. Адаптивність схватів промислових роботів як напрям підвищення ефективності роботизованих механоскладальних технологій. Вісник ЖДТУ. Серія «Технічні науки». 2010. № 1 (52). С. 17-24.

44. Rong W., Liang S., Wang L., Zhang S., Zhang W. Model and control of a compact long-travel accuratemanipulation platform. IEEE/ASME Transactions on Mechatronics. 2016. № 22 (1). P. $402-411$. DOI: https://doi.org/10.1109/TMECH.2016.2597168

45. Wang J., Adib F., Knepper R., Katabi D., Rus D. RF-compass: Robot object manipulation using RFIDs. In Proceedings of the 19th annual international conference on Mobile computing \& networking. 2013, September. P. 3-14. DOI: https://doi.org/10.1145/2500423.2500451

46. Sajjan S., Moore M., Pan M., Nagaraja G., Lee J., Zeng A., Song S. Clear Grasp: 3D Shape Estimation of Transparent Objects for Manipulation. In 2020 IEEE International Conference on Robotics and Automation (ICRA). 2020. May. P. 3634-3642. DOI: https://doi.org/10.1109/ICRA40945.2020.9197518

47. Aulin V. V., Pankov A. O., Zamota T. M., Lyashuk O. L., Hrynkiv A. V., Tykhyi A. A., Kuzyk A. V. Development of mechatronic module for the seeding control system. INMATEH - Agricultural Engineering. 2019. № 59 (3). P. 1-8. DOI: https://doi.org/10.35633/INMATEH-59-20

48. Aulin V., Hrynkiv A., Lyashuk O., Vovk Y., Lysenko S., Holub D., Zamota T., Pankov A., Sokol M., Ratynskyi V., Lavrentieva O. Increasing the functioning efficiency of the working warehouse of the «Uvk Ukraine» company transport and logistics center. Communications - Scientific Letters of the University of Zilina. 2020. № 22 (2). P. 3-14. DOI: https://doi.org/10.26552/com.C.2020.2.3-14

49. Collet A., Berenson D., Srinivasa S. S., Ferguson D. Object recognition and full pose registration from a single image for robotic manipulation. In 2009 IEEE International Conference on Robotics and Automation. 2009. May. P. 48-55. DOI: https://doi.org/10.1109/ROBOT.2009.5152739

50. Savkiv V., Mykhailyshyn R., Duchon F., Mikhalishin M. Modeling of Bernoulli gripping device orientation when manipulating objects along the arc. International Journal of Advanced Robotic Systems. 2018. DOI: https://doi.org/10.1177/1729881418762670

51. Mykhailyshyn R., Savkiv V., Duchon F., Koloskov V., Diahovchenko I. Investigation of the energy consumption on performance of handling operations taking into account parameters of the grasping system. 2018 IEEE 3rd International Conference on Intelligent Energy and Power Systems (IEPS). IEEE. 2018. P. 295-300. DOI: https://doi.org/10.1109/IEPS.2018.8559586

52. Mykhailyshyn R., Savkiv V., Duchon F., Maruschak P., Prentkovskis O. Substantiation of Bernoulli Grippers Parameters at Non-Contact Transportation of Objects with a Displaced Center of Mass. 22nd International Scientific Conference Transport Means 2018. Klaipeda, 2018. P. 1370-1375.

53. Mykhailyshyn R., Savkiv V., Duchon F., Chovanec L. Experimental Investigations of the Dynamics of Contactless Transportation by Bernoulli Grippers. 2020 IEEE 6th International Conference 
on Methods and Systems of Navigation and Motion Control (MSNMC). IEEE, 2020. P. 97-100. Doi: https://doi.org/10.1109/MSNMC50359.2020.9255521

54. Mykhailyshyn R., Savkiv V., Boyko I., Prada E., \& Virgala I. Substantiation of Parameters of Friction Elements of Bernoulli Grippers With a Cylindrical Nozzle. International Journal of Manufacturing, Materials, and Mechanical Engineering (IJMMME). 2021. № 11 (2). P. 17-39. DOI: https://doi.org/10.4018/IJMMME.2021040102

55. Giesen, T., Wertz R., Fischmann C., Kreck G., Govaerts J., Vaes J., Verl A. Advanced production challenges for automated ultra-thin wafer handling. In Proc. 27th Eur. Photovoltaic Sol. Energy Conf. Exhib. 2012, September. P. 1165-1170.

56. Офіційний web сайт ABB Robotics, RobotStudio. URL: http://new.abb.com/products/robotics/ robotstudio.

\title{
УДК 621.865
}

\section{ДОСЛІДЖЕННЯ ТОЧНОСТІ ПОЗИЦІОНУВАННЯ ОБ'ЄКТІВ МАНІПУЛЮВАННЯ ЗАХОПЛЮВАЛЬНИМИ ПРИСТРОЯМИ БЕРНУЛЛ В РОБОТОТЕХНІЧНИХ КОМІРКАХ}

\author{
Володимир Савків ${ }^{1}$; Роман Михайлишин ${ }^{1}$; Вадим Пісьціо ${ }^{1}$; \\ Ігор Козбур ${ }^{1}$; Франтішек Духон²; Любош Хованець² \\ ${ }^{1}$ Тернопільський національний технічний університет імені Івана \\ Пулюя, Тернопіль, Україна \\ ${ }^{2}$ Словачький технологічний університет в Братиславі, Братислава, \\ Словачька Республіка
}

\begin{abstract}
Резюме. Забезпечення необхідної точності позиціонування об'єктів маніпулювання захоплювачами Бернуллі в робототехнічних комірках є актуальним завданням і може досягатися за рахунок вибору рачіональних параметрів процесу захоплення. Проведено експериментальні дослідження процесу захоплення захоплювачами Бернуллі об'єктів маніпулювання при різних експлуатаційних параметрах та їх вазі. Для цього розроблена експериментальна установка, яка складається $з$ промислового робота IRB 4600, контролера IRC5, мікроконтролера Raspberry Pi та двох мікрометрів годинникового типу. Представлено методику визначення сумарної похибки позиціонування системи «робот-захоплювач-об'єкт» щцо враховує похибки позиціювання промислового робота, похибки розмімення затискного пристрою та похибки базування об'єкта маніпулювання відносно осі симетрії захоплювального пристрою. Програмування промислового робота ABB IRB 1600 здіснювалось у середовищі $A B B$ RobotStudio з метою циклічної імітаџіï вантажно-розвантажувальної операчії та визначення відхилення положення об'єкта маніпулювання після його захоплення з різної відстані. Перший ичикл автоматичного режиму роботи використовувався для калібрування мікрометричних індикаторів. При цьому захоплення об’єкта здійснювалося з відстані, щцо дорівнювала 0.02 мм. Для кращої достовірності результатів досліджень проведено 20 ииклів вимірювання для кожного зі змінюваних параметрів. У результаті встановлено, що максимальна похибка базування об'єктів не перевищує 0.4 мм. При захопленні об'єктів з відстані 0.5... мм середнє значення похибки базування становитиме $0.08 \ldots 0.15$ мм, при середньому квадратичному відхиленні-0.025..0.035 мм. Проведено дослідження впливу зміщення $\Delta$ центру мас захоплюваного об'єкта відносно осі захоплювача Бернуллі на точність базування об'єктів. Встановлено, щзо при зміменнях центру мас захоплюваних об'єктів відносно осі захоплювача Бернуллі до 20 мм максимальна похибка базування об'єктів зростає в 2.2 раза.

Ключові слова: промисловий робот, транспортування, маніпулювання, захоплювальний пристрій Бернуллі, точність, позичіонування.
\end{abstract}

https://doi.org/10.33108/visnyk_tntu2021.02.021

Отримано 29.05.2021 